\title{
Political dynamics and religious change in the late pre-colonial Banda Islands, Eastern Indonesia
}

\author{
Peter V. Lape
}

\begin{abstract}
Recently completed archaeological survey and excavation, in conjunction with a re-analysis of historical documents and oral histories, brings to light new evidence about the pre-colonial (tenth to seventeenth centuries) society of the Banda Islands, once the world's sole source of nutmeg. The new data challenge historical assumptions about settlement, Islamization and the nature of trade networks in pre-colonial Banda. They also have implications for the history of conflict between Bandanese and European colonizers, which resulted in genocide, enslavement or forced migration of the Bandanese population in the $1620 \mathrm{~s}$, and the beginning of the colonial era in what is today Indonesia.
\end{abstract}

\section{Keywords}

Culture contact; colonialism; Islamization; spice trade; Indonesia; Maluku.

Island Southeast Asia was in many ways the ultimate goal of European explorers and traders during the 'age of discovery', and the site of some of the earliest European colonial projects. As for other colonial sites in the New World and Africa, historical documents dating from the earliest days of colonialism in Island Southeast Asia are overwhelmingly penned by Europeans. Island Southeast Asia was also a place of unprecedented intensity of long-distance trade and cross-cultural interaction for centuries before the arrival of Europeans, but the pre-colonial documentary record is fragmentary. These factors make the region an ideal, though largely unexplored, place for the archaeological study of culture contact and colonialism.

This paper presents a summary of the results of an archaeological and historical investigation into culture contact in the Banda Islands of what is today the eastern Indonesian province of Maluku (see Lape in prep. for a comprehensive discussion of the research). These eleven small volcanic islands were once the world's sole source of nutmeg and mace, the 'fragrant gold' that later helped finance the riches of seventeenth-century Holland. While it was historically important as the first foothold of what became the Dutch empire 
in the East Indies, we know little of the trajectory of Bandanese history until it collided with that of an expanding Europe in $\mathrm{AD} 1512$, when the first Portuguese ships dropped anchor under the smoking Gunung Api volcano. That history became sharply defined in April of 1621. Over the course of a few months, Dutch East India Company (VOC) forces, aided by Japanese mercenaries, massacred, enslaved or banished some 90 per cent of Banda's population, and the islands were subsequently repopulated by Dutch planters and their Asian slaves (Hanna 1978; Loth 1995a, 1995b, 1998).

The aims of my research have been to illuminate pre-colonial Bandanese social and political development, with a focus on the period from the tenth to seventeenth centuries. Working with the relatively few European historical documents available (dating from 1512 to the 1621 conquest), some historians have presented a picture of pre-conquest Bandanese society as homogeneous and culturally static (Hanna 1978; Masselman 1963). The archaeological evidence suggests a different story of Banda as a dynamic society in a zone of culture contact characterized by shifting and cross-cutting social categories. Here I use archaeological data in combination with historical documents, including previously under-utilized non-European sources, to situate the processes of culture contact and change more firmly in time and local space. In particular, the archaeological evidence suggests that Banda's society was affected by early contacts with long-distance traders, and that the process of Islamization began earlier, but was less monolithic or 'complete' than historians have previously concluded. During the sixteenth to early seventeenth centuries, it was competing social factions rather than a unified opposition that characterized Banda's encounter with Europe.

\section{Banda before Europe: initial colonization and early contacts}

The Banda Islands consist in part of the remains of a large exploded volcanic mountain (Vulkanologi 1988). Gunung Api, the remnant volcanic cone, is still active, last erupting in 1988. The inner islands of Banda Naira, Banda Besar, Pulau Pisang, Pulau Karaka and Gunung Api are mountainous and forested, with volcanic soils. The outer islands of Pulau Hatta, Pulau Ay, Pulau Nailakka, Pulau Rhun and Pulau Manukan are uplifted limestone, and are flatter and dryer than the inner islands (see Fig. 1). ${ }^{1}$

Although the Bandas appear isolated, they have been visited by numerous 'arrivals' since the earliest human history. Located in Wallacea, a biogeographical region sandwiched between the Pleistocene landmasses Sunda and Sahul, Banda was never connected by land bridges to the Asian or Australian continents even during sea-level minimums, and all life forms present in the region would have had to cross open sea to reach the islands. Banda is near one of the several possible migration routes used by the first human colonizers to cross from Southeast Asia to New Guinea and Australia between 40,000 and 60,000 years ago (Spriggs 1998: 51). Researchers have dated the earliest evidence of human presence on other islands in Maluku (at Gebe Island) to at least 32,000 BP (Bellwood 1997: 87), and earlier dates are expected as research continues.

Later, during the so-called Austronesian expansion, new technologies, or possibly a new population, reached Maluku between 4500 and 3500 BP from a Taiwanese homeland. During this period, the Maluku region saw the introduction of domestic animals like the 

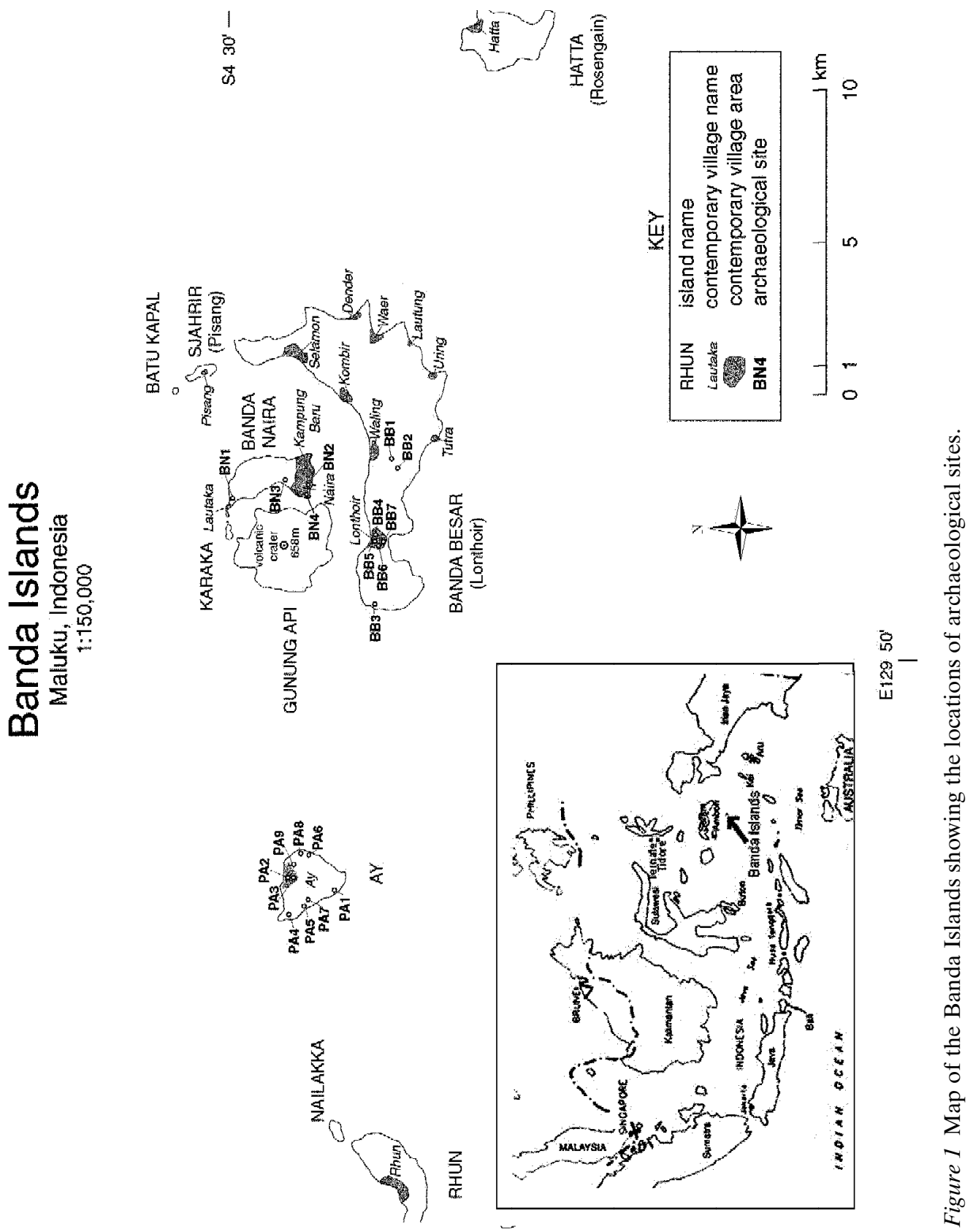


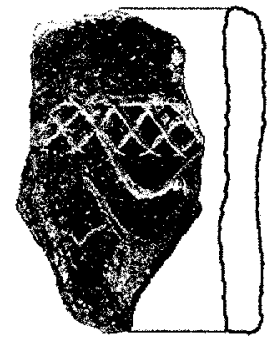

a.

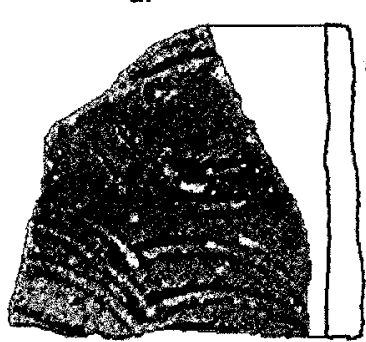

c.

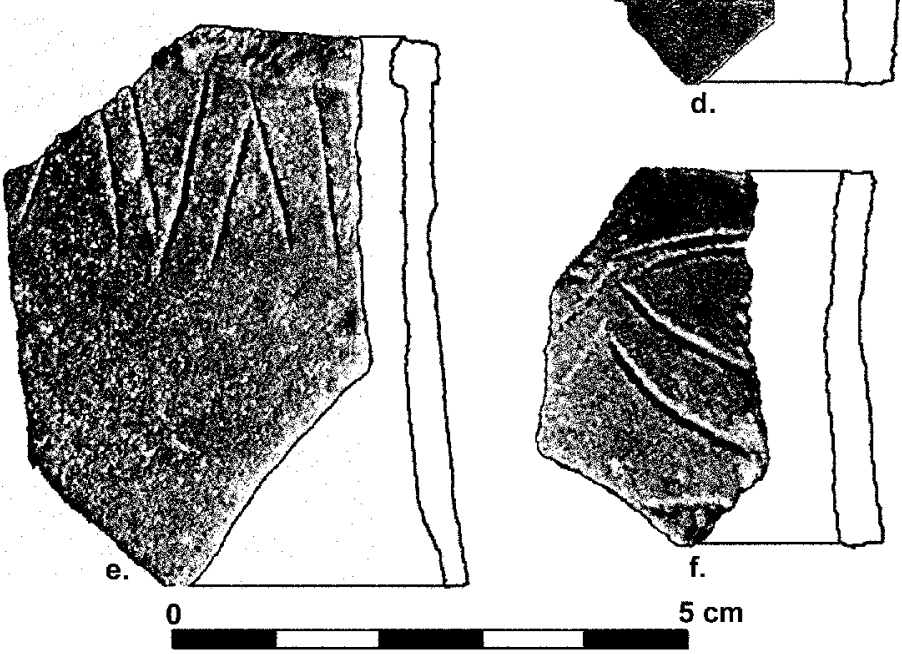

Figure 2 Decorated earthenware pottery sherds from Banda archaeological sites. a: site PA1 unit 1, approx. 3000 BP; b: BN4 Unit 1, approx. 500 BP; c: BN4 unit 1, approx. 400 BP d: BN4 unit 1, approx. 600 BP; e: BN2 unit 2, approx. 500 BP; f: BN4 unit 1, approx. 400 BP

pig, pottery and the Austronesian language family (Bellwood 1997: 201-57; Bellwood et al. 1995; Spriggs 1998). Ceramic-bearing layers at site PA1 on Pulau Ay (see Figs 1 and 2) have been dated to approximately $3150 \mathrm{BP}$, as old as the oldest pottery found in Maluku to date (Bellwood 1997: 229), and ceramics probably somewhat older are present in deeper undated layers at this site.

Increased communication with mainland Southeast Asia, brought metal, including Dong Son-type metal drums, to the region about 2000 years BP (Bellwood 1997: 268-307; Spriggs and Miller 1988). Bellwood (1997) theorizes that Asian traders participating in the nascent spice trade may have carried these artefacts and metal-working technology to Maluku. Other early evidence for contact between Maluku and mainland Asia during this period includes textual references to cloves (for which islands in northern Maluku were the sole source) and possible Maluku place names in Han Chinese documents dating from the first century BC (Andaya 1991). A description of cloves by Pliny in Rome in the first 
century AD documents the long reach of trade networks already established between outer Island Southeast Asia and Europe at that early date (Glover 1990: 1; Miller 1969: 58-60). Evidence for much earlier contact is uncertain. A single purported clove found in an archaeological context from the site of Terqa, Syria, which was dated 4500 BP may not be a clove at all (Spriggs 1998: 57).

For Banda itself, documentary evidence for contact with mainland Asia and points west dates considerably later. Banda's first mention in a Chinese text (Dade Nanhai zhi) dates to AD 1304 (Ptak 1992: 29), and there is a detailed description of Banda in Daoyi zhilue dating to the mid-fourteenth century (Ptak 1998: 130; Rockhill 1915: 256-7). The first mention of Banda in a Javanese text occurs in the Majapahit epic poem Desawarnana, which dates to AD 1365 (Prapañca and Robson 1995: 34), and Chinese texts from this period also mention nutmeg and mace in Javanese port markets (Nastiti 1995). Despite the florescence of Arab travel and navigation in the ninth to eleventh centuries, there is no documentary evidence that Middle Eastern traders visited eastern Indonesia until the later fifteenth century (Tibbetts 1979). Although there are mentions of nutmeg and cloves beginning in the tenth century, they are vague about the geographical origins of these spices (Tibbetts 1979: 31, 38, 100-41), although one early source (Ibn Khurdadhbih, in c. AD 850) correctly situates the 'islands of spices' as fifteen days sail from the island of 'Jaba' (Java?) (Tibbetts 1979: 29). In general, these early sources suggest that longdistance traders may have reached as far as Banda sporadically by the ninth century, with more definite evidence (in the form of detailed descriptions) for regular contacts beginning in the mid-fourteenth century.

The archaeological evidence generally supports this reading of the documents. The earliest exotic trade good identified in Banda to date is a fragment of Chinese pottery deposited in layers dated between $\mathrm{AD} 560$ and 770 at site BN1 on Banda Naira Island. Chinese artefacts appear more regularly in Banda assemblages in post-tenth century contexts. Song Dynasty (AD 960-1279) ceramics and coins were recovered in levels dating from before $\mathrm{AD} 1250$ at BN1 and in several other sites in Banda. While Chinese pottery does not require Chinese traders to carry it to Banda, the rapid increase in volume of Chinese ceramics in Banda sites, particularly after the twelfth century, suggests that direct contact may have been occurring by this time.

Evidence for contact with regions to the east, such as New Guinea and Melanesia, is more enigmatic. New Britain obsidian has been found in the first millennium BC site of Bukit Tengkorak in Sabah, northern Borneo, 8000 kilometres west of its apparent source (Bellwood and Koon 1989). As Melanesia lacks the long written record of China, it will be more difficult to document interaction between these two spheres. Obsidian found in site PA1 in 3000 years BP contexts has not yet been sourced. However, contact between Banda and regions to its east probably played an important role in its late pre-colonial history (Goodman 1998; Swadling 1996).

By the thirteenth century $\mathrm{AD}$, there is evidence for more frequent contact between Banda and other regions. Three sites in Banda have deposits of Song dynasty ceramics (BN1, BN4 and PA2), and radiocarbon dates support thirteenth-century dates for the stratigraphic levels that contain the ceramics. Between the twelfth and the fifteenth centuries, settlements at sites BN1 and BN4 appear to grow in area. BN1 extends from its origins near the beach line over 100 metres to the back of the flat valley by the fifteenth 
century, and was probably the historic village of Labbetakka. From its origins near site $\mathrm{BN} 4$ sometime before the twelfth century $\mathrm{AD}$, this settlement probably incorporated site BN2, 400 metres to its east, by the fifteenth century, becoming the historic village of Nera.

All sites in Banda had large quantities of earthenware pottery in assemblages, including some with red slip and incised linear decorations (see Fig. 2). Site BN1 had a unique (in the Bandas) complex of incised earthenware pottery and sculpted earthenware fragments in the shape of abstract animals, such as bird heads (see Fig. 3). A similar bird-head fragment has been collected by Bellwood on the surface of the eroding Sabatai Tua site on Morotai Island in north Maluku, associated with Chinese blue and white pottery, which he characterizes as a possible pestle for betel preparation (Bellwood et al. 1993: 28-9). Mahirta has recovered somewhat similar pieces in Mare Island, north Maluku (Mahirta 1996: 95-7), as has Latinis in surface collections on Ambon and Seram, central Maluku (Latinis pers. comm.). At site BN1, these sculpted and heavily decorated earthenwares were often associated with fragmented burned bone, ash and human and pig teeth, suggesting it may have been a site for non-Islamic cremation burials and associated feasting. This complex first appears in levels dated around approximately $\mathrm{AD}$ 600, and it abruptly disappears from assemblages at around AD 1600.
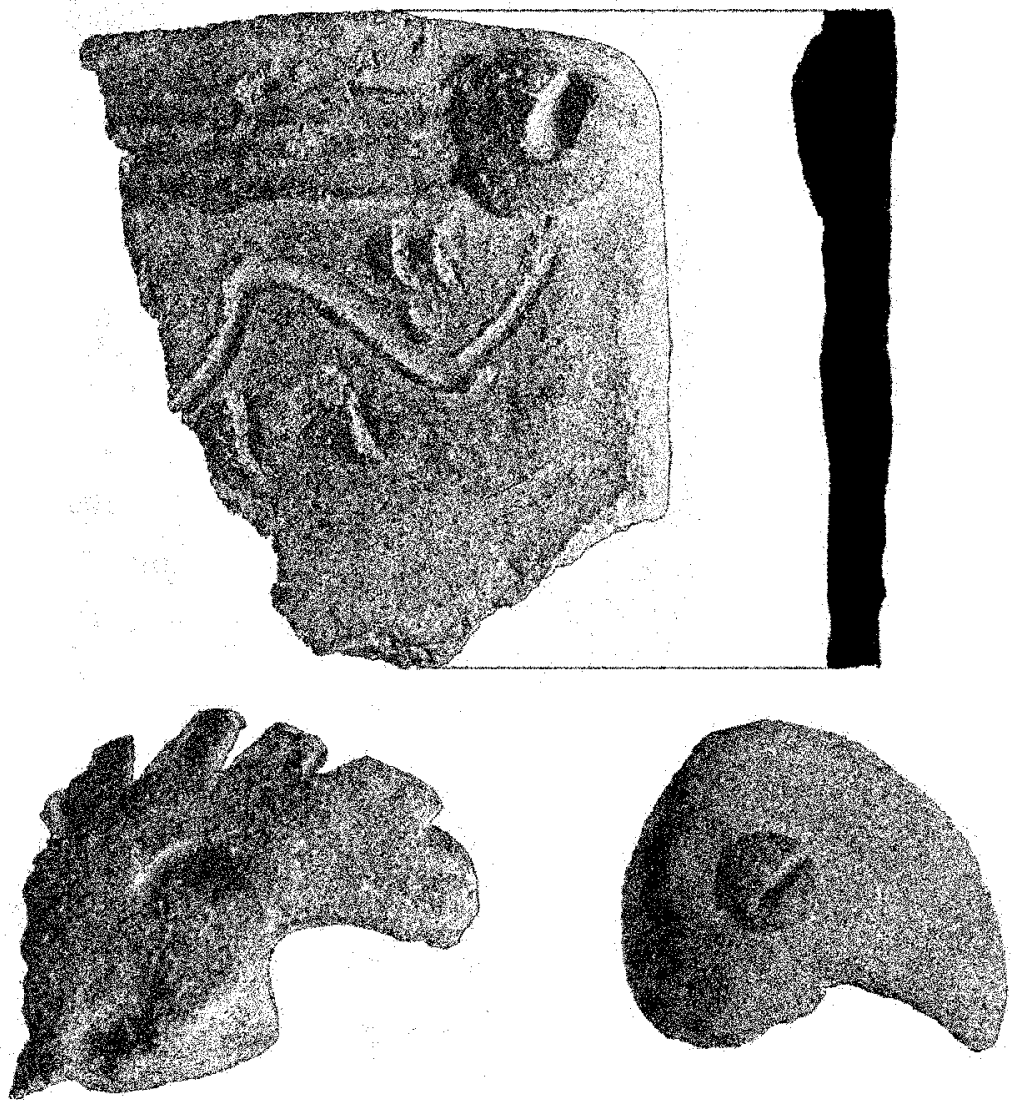

$5 \mathrm{~cm}$
Figure 3 Decorated and 'sculpted' earthenware pottery from site BN1 Unit 3, approx. 500-1000 BP. 
Earthenware pottery recovered in Bandanese archaeological contexts does not seem to have any decorative similarity to contemporary pottery produced in Banda Eli, a Bandanese refugee community on Kei Besar island, some $375 \mathrm{~km}$ southeast of Banda. This village, along with several others on the Kei Islands and in Southeast Seram, was settled by refugees from Portuguese and Dutch attacks in the early seventeenth century. Banda Eli oral history holds that pottery making was a tradition brought from Banda in their flight, and is an integral part of their cultural identity in the Kei Islands (Collins and Kaartinen 1998; Stejskal 1988), but decorative traditions appear to have changed. Earthenware from Banda is also distinct from contemporary Mare (north Maluku) pottery, though some ancient Mare design elements also appear in Banda earthenware (compare Mahirta 1996 with Figure 2). Banda's earthenware decorations show no similarity with those used on (decorated) Ouw pottery produced on Saparua that I saw in 1997 either (Spriggs and Miller 1979). However, both the Ouw and the Banda Eli decorations are generally applied red slip or paints, and it is possible that this pigment has faded or worn off on many of the archaeologically recovered fragments from Banda. In general, however, earthenware found in Banda is similar to that found elsewhere in the region, and it is likely that future archaeological excavations will reveal a regional tradition with some local variations. The well-integrated local trade networks described by the earliest Portuguese documents support the archaeological evidence for significant inter-island contact, exchange of ideas and trade, which may have included earthenware pottery (Barbosa 1921; Pires and Rodrigues 1944).

The archaeological and documentary evidence generally support the idea that Banda was a place of trade and contact with people from both the local region and further away. However, contact with outsiders had deeper implications for people in Banda than simply bringing new material objects to the islands. New ideas and social strategies, particularly those associated with Islam, were sweeping through island Southeast Asia from at least the thirteenth century in a process of Islamization that continues today (Ricklefs 1979). The primary focus of my research in Banda has been to study that process on a local scale, situating it in both the larger context of the Southeast Asian 'age of commerce' and the particular forces and historical trajectories at work in Banda itself.

\section{Islamization in Banda}

The adoption of Islam by the Bandanese during the early modern era was perhaps the most important consequence of Banda's attraction to long-distance trade. In 1512, Tome Pires reported that 'It is thirty years since they began to be Moors in the Banda Islands' (Pires and Rodrigues 1944: 206). If we take these words as fact, Banda was one of the earliest places in eastern Indonesia to convert to Islam. ${ }^{2}$ While there is also archaeological and documentary evidence for a significant non-Islamic presence in Banda throughout the late pre-colonial period, Islam defined, to a large degree, Banda's interaction with the outside world, particularly with Europeans. The characterization of Bandanese society as Islamic put it automatically in the category of enemy to the Portuguese crown, which was still (symbolically anyway) engaged in the crusades, pushing the 'Moors' back in the world (though trading with them peacefully when advantageous). It was also used 
by the Dutch and the English in sporadic, entirely unsuccessful calls to quit fighting each other and join forces against the 'infidel Moors' (Sainsbury 1878: 8). For many people in Maluku, Islam provided an important ideological framework for resisting European cultural influence and political control, and for unifying otherwise divergent political entities (Andaya 1993; Reid 1993b: 147). Islam was a political tool used by leaders both to consolidate their power in monarchical forms favoured in Islamic doctrine and to demonize their opponents and their attempts to control trade and politics (Johns 1995; Reid 1995; Ricklefs 1979).

Why did people convert to Islam? Insoll (1996) proposes various reasons. It may have been genuine shift in belief, as Muslim and other religious scholars generally propose. It may have been the attraction of Islam's apparent power in magic and ritual, and the prestige associated with possessing those powers. It may have been its benefits for trade and administration, such as providing security and comfort for visiting Islamic traders, simplified administration using written Arabic language and the fixed calendar using the lunar cycle. Insoll proposes that it held particular appeal for town dwellers in urban, multiethnic population centres. It appealed to nomads (like long-distance traders) because of its lack of a hierarchical priestly system. It may have had less appeal for sedentary agriculturists, as it did not fit as well with a farmer's life which revolves around crops, and for which animism supplied better answers (Insoll 1996: 90-2). Reid, summarizing Horton, O'Connor and Hoskins, adds that for the maritime traders in Southeast Asia, Islam was attractive because it was 'portable'. It did not require reference to permanent landmarks in a home landscape, but made sense anywhere, and furthermore did not subject the traveller to unknown spirits manipulated by his enemies (Reid 1993a: 159).

But how was Islamic belief and behaviour adopted by the multi-ethnic, dynamic society evolving in Banda? It would appear that the process of Islamization took several centuries, and remained incomplete at least into the early sixteenth century. The description of Banda in Daoyi zhilue, which was probably an account of actual visits to the islands by Wang Dayuan in the 1330s, makes no mention of Muslims, though he is aware of them in other places in Southeast Asia (Ptak 1995, 1998; Rockhill 1915: 256-7). The first historical mention of Muslims in Banda is by the Portuguese chronicler Tome Pires, who reports that 'they began to be Moors' only since the 1480s. Not everyone in Banda was Muslim by 1512, as Pires notes the presence of 'a few heathen inside the country' of the islands, while 'Moorish merchants' inhabited the seacoast (Pires and Rodrigues 1944: 206). Early descriptions of Ternate, in north Maluku, similarly portrayed the Sultan as nominally Muslim, but as surrounded by subjects who had no knowledge of Islamic behaviour or doctrine (Pires and Rodrigues 1944: 213).

The archaeological evidence suggests a Muslim presence in Banda somewhat earlier than these documents report. Additionally, while historical references after the midsixteenth century portray Banda as entirely Muslim, the archaeological evidence suggests that small non-Islamic factions may have remained important up to the 1621 conquest. Religious identity or behaviour is difficult to detect archaeologically. I have used the presence or absence of pig remains and, where possible, human burial traditions as indicators. While there is some debate about the level of compliance of newly converted Island Southeast Asian Muslims with Islamic doctrine, renouncing pork appeared to be a public gesture of central importance, along with circumcision and prayer (Insoll 1999: 96-102; 
Reid 1993b: 141). Islamic law proscribes primary inhumation burials, whereas cremation, or in some cases secondary inhumation, was widely practised in pre-Islamic Indonesia (Bulbeck 1997; Insoll 1999; Reid 1995). If these observations held for Muslims in precolonial Banda, then the presence of pig bones and cremated human remains in archaeological sites suggests that non-Muslims occupied those sites.

As expected, pig (Sus sp.) bones and teeth, along with the bones of birds and large reefdwelling fish species, are prominent in the faunal assemblages of sites PA1 and the lower levels of sites BN1, and in the lower levels of some test pits dug on Banda Besar and Pulau Ay (Groves 1981; Groves 1995). However, site BN1 (representing the historic town of Labbetacca) had large quantities of pig remains present in layers dating between initial occupation around AD 500 up until the late sixteenth century, well into the 'Islamic period' in Banda. The pig remains are associated throughout this period with burned fragmented human bones and ash (suggesting cremation burials) and the sculpted earthenware tradition, neither of which were found anywhere else in the Bandas. The disappearance of pig bones coincides, stratigraphically, with the first appearance of Swatow blue and white tradewares, dated to the late sixteenth century (see Fig. 4), as well as the disappearance of burned human bone and sculpted earthenware. This change also coincides with a shrinking of the occupied area of the site, and an overall decrease in the density of artefact deposition.

In contrast, sites BN2, BN4 (probably the town of Nera) and PA2 (probably the town of $A y$ ) had no pig remains from their initial occupation until after the seventeenth century,

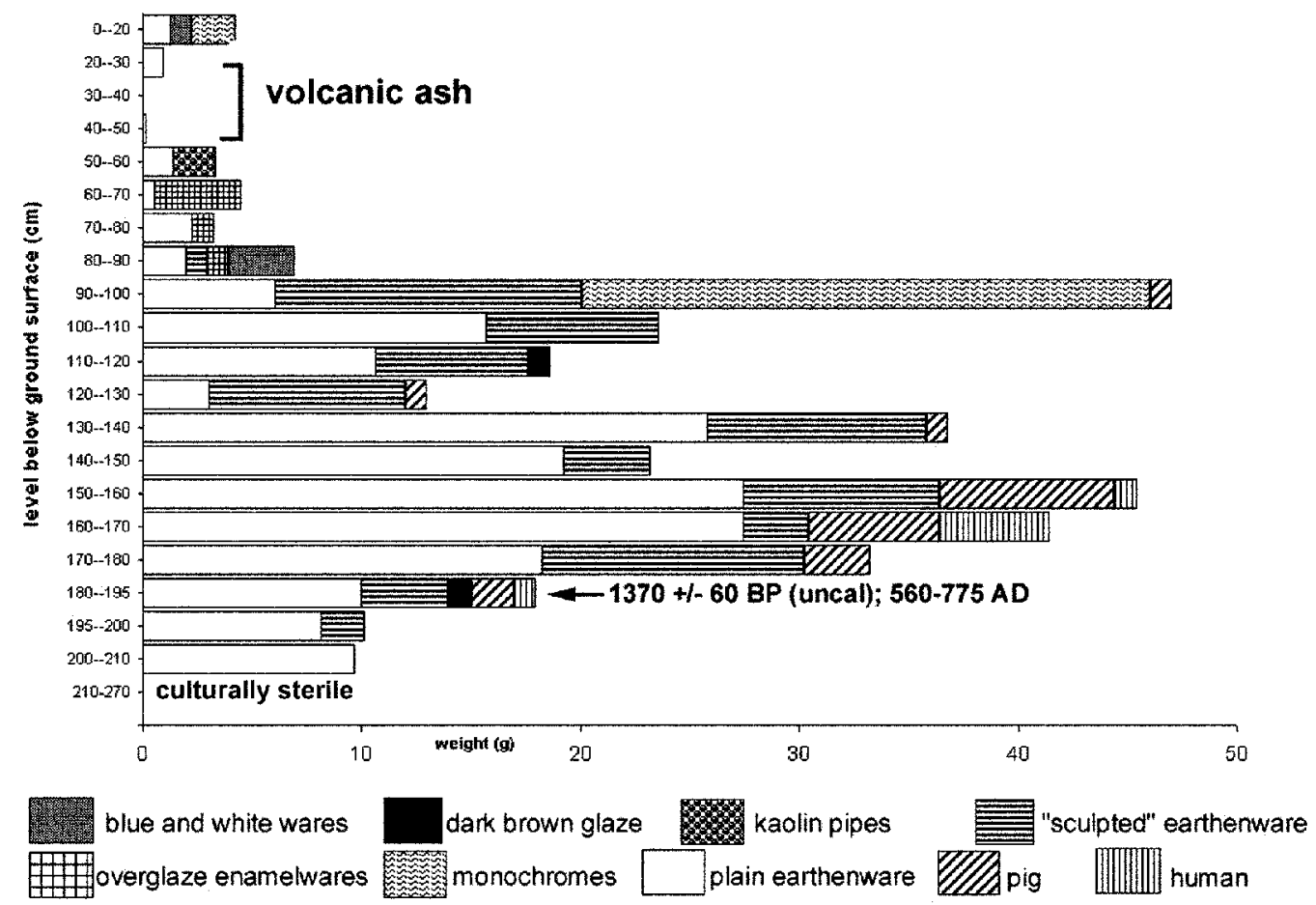

Figure 4 Artefact assemblages from site BN1 Unit 3. 
when Dutch colonists occupied these settlements, although they were rich in fish and bird bones. ${ }^{3}$ Sites BN4 and PA2 were initially occupied before the twelfth century, and BN2 was occupied by the thirteenth century. None of these sites contained any human remains, nor did they contain the sculpted earthenware tradition. These three sites are distinct from site $\mathrm{BN} 1$ in that they are located geographically on the best ports of the two islands, whereas site BN1 is on an exposed coast unsuitable for anchorage. Site BN1 is in an arguably more defensive position, being surrounded by high bluffs, whereas BN2, BN4 and PA2 are on largely flat, open sections of coastline. I suggest that sites BN2, BN4 and PA2 represent settlements oriented towards long-distance trade, and which were inhabited primarily by Muslims. Perhaps they were enclaves of 'foreign' Muslims who lived in Banda while trading and waiting for the change in monsoon winds.

This interpretation of the archaeological evidence is not obviously supported by documentary data. While the Portuguese and Dutch documents suggest Nera was a Muslim enclave in the sixteenth century, Muslims are not reported in Banda by the fourteenthcentury Chinese reports. However, small Muslim communities were already present in trading ports in Southeast Asia in the first millennium, and had become more established in Sumatra by the end of the thirteenth century (Reid 1993b: 132). Banda's importance as the source of nutmeg and mace could mean that communities of Muslim traders were established in Banda, at least occasionally, quite early on.

The documents similarly do not obviously support the archaeological evidence of the continued presence of non-Muslim communities in Banda after Tome Pires. However, a re-reading of the documents in light of the archaeological evidence highlights some 'between the lines' evidence for the continued presence of non-Muslims in Banda throughout the sixteenth and early seventeenth centuries, and geographical separation of Muslims and non-Muslims into distinct settlements. For example, a Portuguese narrative from 1529 distinguishes between indigenous Bandanese and foreign Muslims, framing their relations as rather contemptuous:

three of these islands, the bigger ones, have Moorish kings, who have little by little made themselves lords of the land (asenhorear), they had the strength to set-up and resist against the natives of those lands, who sought refuge in the mountains from where they launched war; however, now they are on conversing terms with the Moors.

(Sá 1954: 17-18)

In another example, Dutch and English descriptions of the islands from the first decade of the seventeenth century describe violent battles between two alliances of villages in Banda. One alliance was made up of the villages of Nera, Lonthoir, Ay and Rhun, while the other was made up of Labbetacca, Wayer and Kumbir. The cause of the conflict, according to Dutch observers, was 'the cutting down of certain trees many years since, in the territory of Nera, by the men of Labetacke whence they since kill one another like dogs' (Purchas and Hakluyt 1625: 710). In one description of a battle in 1599 between Nera and Labbetacca, the men of Nera capture and behead several Labbetacca male warriors, then mount the heads on bamboo poles for public display in Nera. ${ }^{5}$ The decapitated bodies of the Labbetacca warriors were disposed in the Islamic fashion, however, wrapped in white cloth and buried, a censer of incense left burning at the graveside through the night (Purchas 1626: 607), though the burial ceremony incorporated non-Islamic components as 
well (Reid 1995: 323). While we are not told of the Labbetacca burial customs, the presence of burned human bones and teeth associated with the sculpted earthenware artefacts at site BN1 suggests that cremation, a non-Islamic custom, was practised there.

This geographical separation or polarization along religious lines, if it existed at all, must be reconciled with the apparently fluid nature of religious (and ethnic) identity in early modern Southeast Asia, at least until the last decades of the sixteenth century. It would appear that in most of Island Southeast Asia, people moved between the domains of the various religious choices with relative ease, though sometimes with dangerous consequences (Henley 1993: 51-4; Reid 1993a). In late pre-colonial Banda, for example, there are several accounts of conversion, on the part of both the Bandanese and Europeans ('Answer' 1971: 5-10; Astley 1746: 441; Moreland 1934: 89; Purchas et al. 1905: 519). Often this was done, it appears today, more for political or socially strategic reasons than theological ones. Distinct settlements oriented towards either Muslim or non-Muslim behaviour may have had distinct roles in Banda's social economy, and people were able to move between them with relative ease.

One aspect of distinct economic roles played by settlements with different religious orientations is suggested by contemporary settlements in Banda. Feral pigs are a major pest on Banda Besar Island now, seriously damaging crops. One small community of Christians living in the settlement of Spancibi plays an important role in controlling pig populations through hunting them for food. Particularly interesting is the fact that this community is able to grow taro in their village gardens because the pigs have apparently learned to stay away from this settlement, while the largely Muslim villages on the rest of the island are not. Whether this situation also occurred in the past in Banda is open to speculation, but pollen and phytolyth analysis of soils from archaeological contexts is currently in process. The results of these analyses may shed light on the plant component of Bandanese diet, as well as changes in plant communities over time.

Islamization may have had an ecological impact on Banda's small island ecosystem, as increasing numbers of Bandanese observed Islamic prohibitions on eating pig. In Banda's ecosystem, humans are the pig's sole predators (although large constricting snakes may have controlled pig populations somewhat), and, as pig hunting decreased, it is likely that the pig population increased. More pigs would have competed with humans for food, particularly root crops such as taro (Colocasia), and later, European-introduced cassava (Manihot utilissima), possibly reducing the viability of this type of agriculture. Islamization may have had the consequence of increasing reliance on food imports such as sago and rice, which would have further increased the number of mostly Islamic traders in Banda, further fuelling a feedback system proposed by Ellen $(1979,1984)$. However, nonIslamic populations may have countered this effect, and may have played an important role as pig hunters.

In summary, the archaeological evidence of early Muslim 'enclaves' (at sites BN2, BN4 and PA2) and the continued presence of non-Muslim settlements into at least the later sixteenth century (at site BN1) would appear to fit well with theories of Islamic conversion proposed by Insoll for Africa, who proposes a three-stage process: 1) quarantine: Muslim clerics or traders enter an area, a few local people are converted; 2) mixing: indigenous population increasingly converts, but they tend to combine preIslamic beliefs with more fundamental Islam; 3) reform: after a few centuries, a return 
to a conservative fundamentalist Islam (Insoll 1996: 96). The initial appearance of the BN4 enclave may represent the 'quarantine' stage for Banda, while in the sixteenth century, the islands were in the process of moving into stage 2, or 'mixing'. This coincides with the period of rapid conversion to Islam in Indonesia, identified by Reid (1993a) as lasting from 1550 to 1650, and significantly, increasing numbers of Europeans intent on controlling the trade in spices.

\section{Late pre-colonial contacts and conflicts}

By the sixteenth century, it appears that Banda was well connected via trade with mainland Asia. Sixteenth-century assemblages from all sites excavated in Banda contain considerable amounts of glazed ceramics originating from primarily Guangdong and Fujian provinces of China, as well as smaller amounts of Vietnamese and Thai ceramics. Imported ceramics begin to outnumber locally made earthenware pottery at this time. European-manufactured clay tobacco pipes begin to appear in small quantities in all sites beginning in the early seventeenth century.

By this time, Banda had become markedly multicultural. As described by the English Captain Keeling in 1609, Banda was 'a collectious nation of many people compounded' (Purchas and Hakluyt 1625: 710). Throughout the historical documents are references to resident Turks, Persians, Bengalese, Gujeratis, Chinese, Japanese, Malays, Javanese, Macassarese and people from the other Maluku islands of Seram, Ambon, Kei, Ternate, Tidore and Aru (Hanna 1978; Pires and Rodrigues 1944; Purchas and Hakluyt 1625; Villiers 1981, 1990). Most of these 'foreigners' probably lived in ethnic compounds in the major trading villages of Nera, Ay and Lonthoir, as was typical throughout Southeast Asian trading ports. The first Dutch account of Banda from 1599 describes the town of Nera as a 'Javanese' enclave, which by 1609 was populated by some 1500 'Javanese' or at least 'Javanized' residents (Villiers 1981: 727). This enclave may have also been the home of Malays, and the 'Turk' who acted as an intermediary for the Dutch in 1599 ('Tweede' 1601; Reid 1993c: 116).

Historical documents from this period suggest that, along with increased trade, came increased conflict, both internally and with external forces. While the evidence is fragmentary, some Portuguese documents suggest that relations between 'native' Bandanese and 'foreign' Muslims were not entirely friendly, and that there was an element of force behind Banda's adoption of Islam. In 1574, for example, the Portuguese fought against a heavily armed fleet from Jor (Johore) in Banda that may have been engaged in forcefully persuading the people in Banda to join with an increasing organized Muslim resistance to Portuguese interference in trade (Sá 1954: 260-1).

Despite some evidence of conflict with other Islamic polities, by the end of the sixteenth century Banda appears to have become a locus of Islamic resistance to official Portuguese interference in trade and in religious affairs. The Portuguese capture of Malacca in 1511, which appeared to have been the most important market for Bandanese nutmeg and mace, upset trading patterns throughout the archipelago, and temporarily reduced the volume of spice trade throughout Asia (Reid 1993b: 272). Non-European trade, including Banda's share, was subsequently shifted to a half-dozen regional centres, 
all of which became great enemies of the Portuguese, and were the sites of numerous battles and sieges that were framed by the Portuguese chroniclers as anti-Muslim wars. After the Portuguese fall from grace in Ternate in the 1570s, the Ternate sultans became more closely allied with Banda, calling for their help in numerous battles with the Portuguese and their shifting network of allies (Bohigian 1994: 119; Henley 1993; Sá 1954: 330-3, 435-8, 451-1).

Evidence for conflict also appears in the archaeological record in Banda. At the coastal sites BN1 and BN2, the remains of coral and volcanic rock walls were found, dating to the late sixteenth century. At BN1, the remains of this wall were one metre high and ran parallel to the beach approximately 25 metres inland of the mean high-tide line. At BN2, remains of the wall were mixed with lime mortar, and were approximately one metre in height, located about 50 metres inland of the contemporary mean high-tide line. It appears as if this wall was once much taller, and had collapsed to the landward in the late sixteenth to early seventeenth century, as levels covering the ruins contain the oldest clay pipes in the site. It was also much closer to the shore when it was built, as the coastline of southern Banda Naira Island has prograded to the south because of Dutch colonial period building projects (see Fig. 5). There is documentary evidence of walled compounds in the settlement of Nera, as depicted in a map (Fig. 6) first published in the account of a 1599 Dutch expedition to Banda ('Tweede' 1601). By the end of the sixteenth century, defensive walls had been built in many trade ports in Southeast Asia, especially in Java, primarily as a defence against European attacks (Reid 1993b: 88). By 1620, it appears that

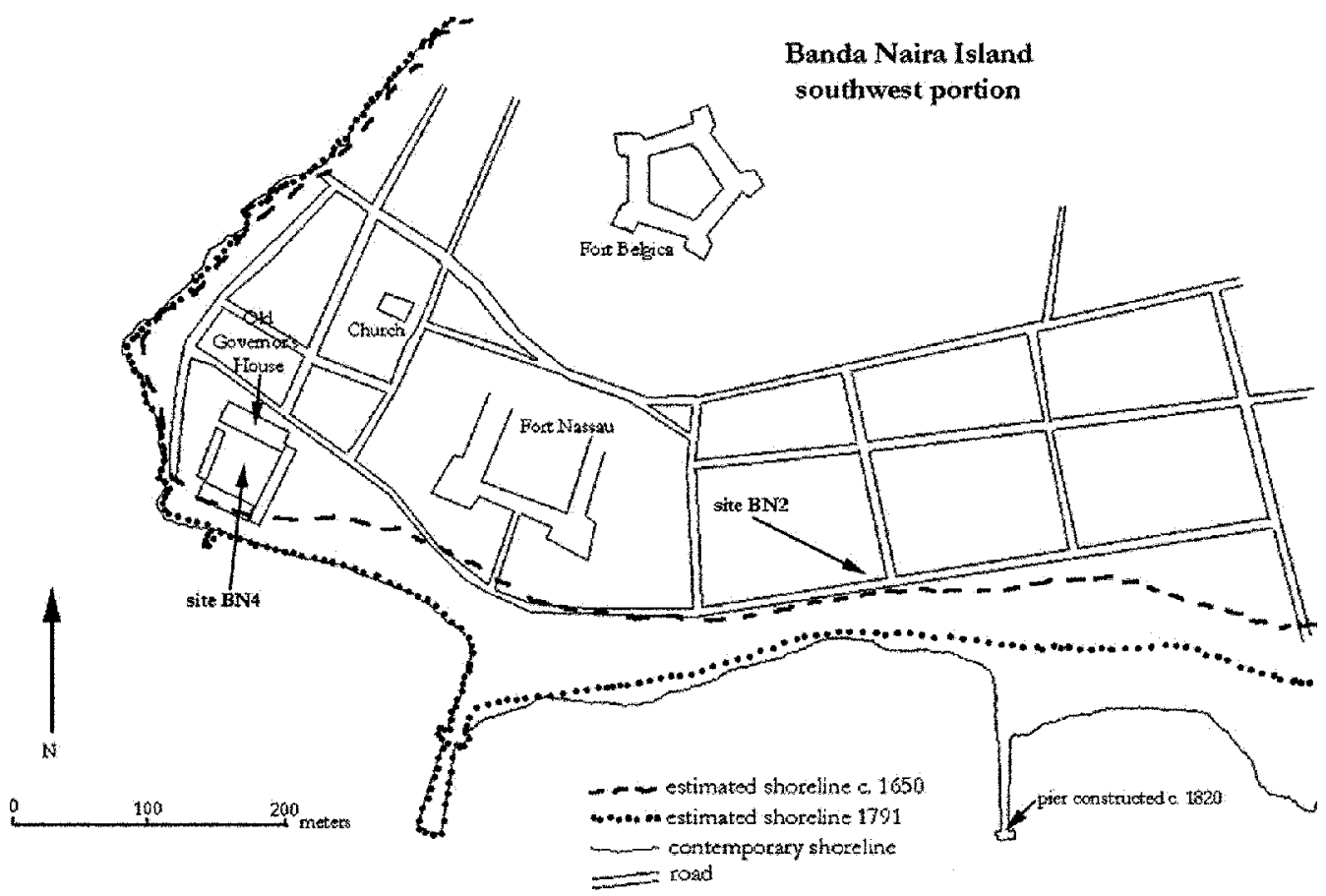

Figure 5 Map of southwestern Banda Naira Island, showing coastal progradation since the seventeenth century. Inferred from seventeenth- to nineteenth-century maps and test excavations. 
$1, \mathrm{k}$, $\mathrm{senhas}$

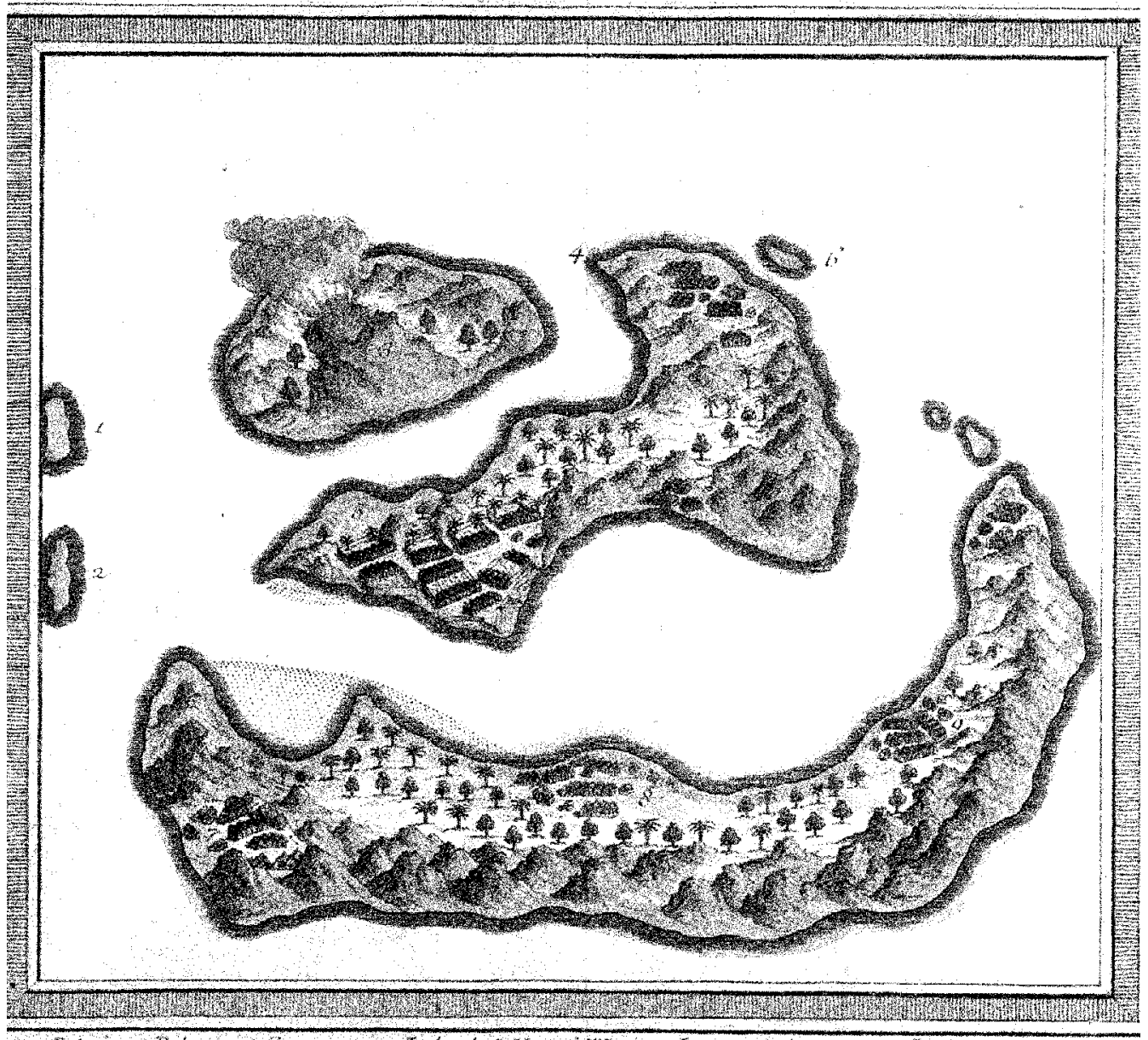

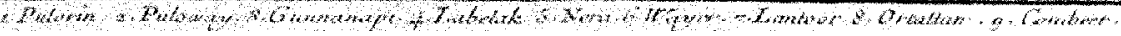

Figure 6 A 1599 Dutch map of the Banda Islands, showing walled compounds in Nera. From author's private collection, probably from the Prevost Atlas, published 1746.

many villages in Banda had built defensive walls, which were ordered torn down by the Dutch as the condition of surrender (Purchas and Hakluyt 1625: 609).

These walls may not have been constructed solely to repel European, or even Southeast Asian invaders. The inter-village conflicts noted by early seventeenth-century documents, particularly between the two village alliances that pitted Nera against Labbetacca, may also have provided a rationale for their construction. However, the archaeological evidence remains inadequate to tell the story of the final years of these two villages leading up to the Dutch conquest. Although site BN1 shows a dramatic change in size and density of occupation, it is impossible to determine whether this happened before or after the 1621 massacre. The documents suggest Labbetacca was losing population before the massacre, however. The Dutch encountered little resistance from Labbetacca during a preemptive raid on the village in the late sixteen hundreds, killing several women and smashing their cooking pots, and the village disappears from the maps after 1621 (Purchas 
1626). Nera, on the other hand, remained a well-organized anti-Dutch stronghold until the final days, and later became the centre of the new colonial settlement system. I would suggest that Labbetacca's fall had much to do with its decreasing influence as a nonMuslim entity in the face of the need for organized Muslim resistance to Portuguese and Dutch intrusions.

\section{Summary}

While historians have tended to portray society in late pre-colonial Banda as culturally static and homogeneous, recent archaeological research has highlighted the rapid changes in material culture, settlement systems and population, particularly during the twelfth to seventeenth centuries. Most importantly, the various changes, particularly those associated with Islamization, did not occur all at once across Banda's social landscape. The earliest evidence for a Muslim presence occurs somewhat earlier than suggested by historical documents, but some settlements in Banda appear to have remained non-Muslim up to the last decades before the 1621 conquest. There is the possibility that this internal heterogeneity had functional advantages in Banda's small island ecosystem. Non-Muslim villages in Banda may have also had advantages in trading with other non-Muslim areas, particularly the sago-producing areas to the east of Banda. A re-reading of the historical documents, particularly those that note violent inter-village warfare, add credence to the archaeological evidence for conflict embodied in defensive coastal-wall construction. In general, archaeological research in Banda has proved effective in highlighting particular and localized factors that affected complex, long-term social processes, such as crosscultural trade, culture contact and Islamization.

Department of Anthropology

Brown University, Providence

\section{Notes}

1 Names and spellings of islands and villages are as currently used in Banda. Historic place names are italicized. The islands of Rozengain and Pisang were renamed Hatta and Syahrir after the two Indonesian nationalist heroes who were imprisoned in Banda in the 1930s, but Pisang remains in popular use.

2 Pires states that Ternate's 'conversion' occurred fifty years before 1512, making it twenty years before Banda's (Pires and Rodrigues 1944: 213). A 1529 description states that the islands had been 'Moorish' for seventy years (Sá 1954: 15).

3 After the seventeenth century, pig remains re-appear in most Banda sites in Dutch colonial contexts (see Loth 1998 on Dutch colonial foodways in Banda).

4 Translated from Portuguese by Isabel Rodrigues.

5 The Bandanese (probably also from Nera) do the same with the heads of Dutch soldiers they massacre a few years later, and, in potent use of local symbols, so do the Dutch with the heads of massacred Bandanese orang kaya in 1621. 


\section{References}

'Answer'. 1971. An answer to the Hollanders Declaration, concerning the Occurents of the East India, written by certain mariners, lately returned from thence into England. Amsterdam: De Capo Press.

'Tweede'. 1601. Het tvveede boeck, journael oft dagh-register, inhoudende een warachtich verhael ende historische vertellinghe vande reyse, gedaen door de acht schepen van Amstelredamme, gheseylt inden maent martij 1598. onder 'tbeleydt vanden Admirael Iacob Cornelisz. Neck, ende Wybrant van VVarvvijck als vice-admirael. ... Met ... een vocabulaer van hare woorden. Middelburg: Barent Langhenes.

Andaya, L. 1991. Local trade networks in Maluku in the 16th, 17th, and 18th centuries. Cakalele, 2: $71-96$.

Andaya, L. 1993. The World of Maluku: Eastern Indonesia in the Early Modern Period. Honolulu: University of Hawaii Press.

Astley, T. 1746. New General Collection of Voyages and Travels, Vol. I: Voyages of the English to the East Indies. London.

Barbosa, D. 1921. The Book of Duarte Barbosa: An Account of the Countries Bordering on the Indian Ocean and their Inhabitants (trans. Mansel Longsworth Dames) (2nd ser., no. 49). London: Hakluyt Society.

Bellwood, P. 1997. Prehistory of the Indo-Malaysian Archipelago. Honolulu: University of Hawaii Press.

Bellwood, P. and Koon, P. 1989. 'Lapita colonists leave boats unburned!' The question of Lapita links with Island Southeast Asia. Antiquity, 63: 613-22.

Bellwood, P., Fox, J. J. and Tryon, D. 1995. The Austronesian in history: common origins and diverse transformations. In The Austronesians: Historical and Comparative Perspectives (eds P. Bellwood, J. J. Fox and D. Tryon). Canberra: Australian National University.

Bellwood, P., Waluyo, A., Gunadi, Nitihaminoto, G. and Irwin, G. 1993. Archaeological research in the Northern Moluccas: Interim results 1991 field season. Indo-Pacific Prehistory Association Bulletin, 13: 20-33.

Bohigian, G. M. 1994. Life on the rim of Spain's Pacific-American Empire: Presidio Society in the Molucca Islands, 1606-1663. PhD dissertation, University of California, Los Angeles.

Bulbeck, D. 1997. The bronze-iron age of South Sulawesi, Indonesia: Mortuary traditions, metalurgy and trade. In Ancient Chinese and Southeast Asian Bronze Age Cultures (eds D. Bulbeck and N. Barnard). Taipei: SMC Publishing.

Collins, J. T. and Kaartinen, T. 1998. Preliminary notes on Bandanese language maintenance and change in Kei. Bijdragen tot de Taal-, Land- en Volkenkunde, 154: 521-70.

Ellen, R. 1979. Sago subsistence and the trade in spices: a provisional model of ecological succession and imbalance in Moluccan history. In Social and Ecological Systems (eds P. Burnham and R. Ellen). New York: Academic Press.

Ellen, R. 1984. Trade, environment and the reproduction of local systems in the Moluccas. In The Ecosystem Concept in Anthropology (ed. E. Moran). Boulder, CO: Westview Press.

Glover, I. C. 1990. Early Trade Between India and South-East Asia: A Link in the Development of a World Trading System, Occasional Paper No. 16. Hull: Centre for East Asian Studies, University of Hull.

Goodman, T. 1998. The sosolot exchange network of eastern Indonesia during the seventeenth and eighteenth centuries. In Perspectives on the Bird's Head of Irian Jaya, Indonesia (eds J. Miedema, C. Odé and R. A. C. Dam). Amsterdam: Rodopi. 
Groves, C. 1981. Ancestors for the Pigs: Taxonomy and Phylogeny of the Genus Sus. Canberra: Australian National University.

Groves, M. 1995. Domesticated and commensal mammals of Austronesia. In The Austronesians: Historical and Comparative Perspectives (eds P. Bellwood, J. Fox and D. Tyron). Canberra: The Australian National University.

Hanna, W. A. 1978. Indonesian Banda: Colonialism and its Aftermath in the Nutmeg Islands. Philadelphia: Institute for the Study of Human Issues.

Henley, D. 1993. A superabundance of centers: Ternate and the contest for North Sulawesi. Cakalele, 4: 39-60.

Insoll, T. 1996. Islam, Archaeology and History: Gao Region (Mali) ca. AD 900-1250. Oxford: BAR International Series 647.

Insoll, T. 1999. The Archaeology of Islam. Oxford: Blackwell.

Johns, A. H. 1995. Sufism in Southeast Asia: reflections and reconsiderations. Journal of Southeast Asian Studies, 26: 169-183.

Lape, P. in prep. Archaeology and History of the Late Pre-colonial Banda Islands, Eastern Indonesia. PhD Dissertation, Deptartment of Anthropology, Brown University.

Loth, V. 1995a. Armed incidents and unpaid bills: Anglo-Dutch rivalry in the Banda Islands in the seventeenth century. Modern Asian Studies, 29: 705-40.

Loth, V. 1995b. Pioneers and Perkeniers: The Banda Islands in the 17th century. Cakalele, 6: 13-35.

Loth, V. 1998. Fragrant gold and food provision: resource management and agriculture in seventeenth century Banda. In Old World Places, New World Problems: Exploring Issues of Resource Management in Eastern Indonesia (eds S. Pannell and F. V. Benda-Beckmann). Canberra: Australian National University.

Mahirta. 1996. The development of Mare pottery in the Northern Moluccas context and its recent trading network. Unpublished master's thesis, The Australian National University.

Masselman, G. 1963. The Cradle of Colonialism. New Haven, CT: Yale University Press.

Miller, J. I. 1969. The Spice Trade of the Roman Empire, 29 B. C. to A. D. 641. Oxford: Clarendon Press.

Moreland, W. H. (ed.) 1934. Peter Floris, His Voyage to the East Indies in the Globe 1611-1615. London: Hakluyt Society.

Nastiti, T. S. 1995. Commerce during the Majapahit period. In The Legacy of Majapahit: Catalogue of an Exhibition at the National Museum of Singapore, 10 November 1994-26 March 1995 (eds J. N. Miksic, E. S. H. Soekatno, National Museum (Singapore) and SNH Board). Singapore: National Heritage Board.

Pires, T. and Rodrigues, F. 1944. The Suma Oriental of Tomé Pires, an account of the East, from the Red Sea to Japan, written in Malacca and India in 1512-1515, and The book of Francisco Rodrigues, rutter of a voyage in the Red Sea, nautical rules, almanack and maps, written and drawn in the East before 1515 (trans. Armando Cortesão) (Works issued by the Hakluyt Society, Ser. 2, no. 89-90). London: The Hakluyt Society.

Prapañca and Robson, S. O. 1995. Desawarnana: (Nagarakrtagama) (Verhandelingen van het Koninklijk Instituut voor Taal-, Land- en Volkenkunde 169). Leiden: Kitlv.

Ptak, R. 1992. From Quanzhou to the Sulu Zone and beyond: questions related to the early fourteenth century. Journal of Southeast Asian Studies, 29: 269-94.

Ptak, R. 1995. Images of maritime Asia in two Yuan texts: Daoyi zhilue and Yiyu zhi. Journal of Sung-Yuan Studies, 25: 47-75.

Ptak, R. 1998. Glosses on Wang Dayuan's Daoyi zhilue. In China and the Asian Seas: Trade, Travel, and Visions of the Other (1400-1750) (ed. R. Ptak). Aldershot and Brookfield, VT: Ashgate. 
Purchas, S. 1626. Pvrchas his Pilgrimage. Or Relations of the world and the religions obserued in all ages and places discouered, from the Creation vnto this present.: Contayning a theologicall and geographicall historie of Asia, Africa, and America, with the ilands adiacent. Declaring the ancient religions before the Flovd, the heathenish, Iewish, and Saracenicall in all ages since (Vol. 5). London: printed by William Stansby for Henrie Fetherstone.

Purchas, S. and Hakluyt, R. 1625. Purchas his pilgrimes. In five books. London: printed by William Stansby for Henrie Fetherstone.

Purchas, S., Hakluyt, R. and Hakluyt Society. 1905. Hakluytus posthumus, or Purchas his Pilgrimes: contayning a history of the world in sea voyages and lande travells by Englishmen and others (Extra series, Hakluyt Society). Glasgow: James MacLehose.

Reid, A. 1993a. Islamization and Christianization in Southeast Asia: the critical phase, 1550-1650. In Southeast Asia in the Early Modern Era: Trade, Power, and Belief (ed. A. Reid). Ithaca, NY: Cornell University Press.

Reid, A. 1993b. Southeast Asia in the Age of Commerce, 1450-1680, Vol. 2: Expansion and Crisis. New Haven, CT: Yale University Press.

Reid, A. (ed.) 1993c. Southeast Asia in the Early Modern Era: Trade, Power, and Belief. Ithaca, NY: Cornell University Press.

Reid, A. 1995. Continuity and change in the Austronesian transition to Islam and Christianity. In The Austronesians: Historical and Comparative Perspectives (eds P. Bellwood, J. Fox and D. Tryon). Canberra: Australian National University.

Ricklefs, M. C. 1979. Six centuries of Islamization in Java. In Conversion to Islam (ed. N. Levtzion). New York: Holmes \& Meier.

Rockhill, W. W. 1915. Notes on the relations and trade of China with the Eastern Archipelago and the coast of the Indian Ocean during the fourteenth century, part II. T'oung Pao, 26: 61-626.

Sá, A. B.d. 1954. Documentação para a História das Missões do Padroado Português do Oriente, Insulíndia (Vol. 4). Lisboa: Agência Geral do Ultramar, Divisão de Publicações e Biblioteca.

Sainsbury, W. N. (ed.) 1878. Calendar of State Papers, Colonial Series, East Indies, China and Japan, 1622-24. London: Longman.

Spriggs, M. 1998. Research questions in Maluku archaeology. Cakalele, 9: 49-62.

Spriggs, M. and Miller, D. 1979. Ambon-Lease: a study of contemporary pottery making and its archaeological significance. In Pottery and the Archaeologist (ed. M. Millett). London: Institute of Archaeology.

Spriggs, M. and Miller, D. 1988. A previously unreported bronze kettledrum from the Kai Islands, eastern Indonesia. Indo-Pacific Prehistory Association Bulletin, 8: 79-88.

Stejskal, E. S. 1988. Banda Ely pottery. Unpublished report prepared for LIPI.

Swadling, P. 1996. Plumes from Paradise: Trade Cycles in Outer Southeast Asia and their Impact on New Guinea and Nearby Islands until 1920. Boroko: Papua New Guinea National Museum.

Tibbetts, G. R. 1979. A Study of the Arabic Texts Containing Material on South-East Asia (Publications. v. 44). Leiden: E. J. Brill for the Royal Asiatic Society.

Villiers, J. 1981. Trade and society in the Banda islands in the sixteenth century. Modern Asian Studies, 15: 723-50.

Villiers, J. 1990. The cash crop economy and state formation in the Spice Islands in the fifteenth and sixteenth centuries. In The Southeast Asian Port and Polity: Rise and Demise (eds J. KathirithambyWells and J. Villiers). Singapore: Singapore University Press.

Vulkanologi, D. 1988. Gunung Banda-Api. Berita Berkala Vulkanologi Edisi Khusus No. 115. 